\title{
Prediction of benthic impact for salmon net-pens based on the balance of benthic oxygen supply and demand
}

\author{
Robert H. Findlay ${ }^{1, *}$, Les Watling ${ }^{2}$ \\ 'Department of Biochemistry, Microbiology and Molecular Biology and Center for Marine Studies, Darling Marine Center, \\ University of Maine, Walpole, Maine 04573, USA \\ ${ }^{2}$ Darling Marine Center, University of Maine, Walpole, Maine 04573, USA
}

\begin{abstract}
The ratio between oxygen supply and oxygen demand was examined as a predictor of benthic response to organic enrichment caused by salmon net-pen aquaculture. Oxygen supply to the benthos was calculated based on Fickian diffusion and near-bottom. flow velocities. A strong linear correlation was found between measured carbon sedimentation rates and rates of benthic metabolism. This relationship allowed an estimation of oxygen demand based on sedimentation rates. Comparison of several production sites in Maine (USA) coastal waters showed that for sites where oxygen demand exceeded supply benthic impacts were high and for sites where oxygen supply exceeded demand benthic impacts were low. These findings were summarized in the form of a predictive model that should be useful in siting salmon production facilıties.
\end{abstract}

KEY WORDS: Aquaculture Benthic metabolısm - Marine pollution

\section{INTRODUCTION}

As salmonid net-pen culture has become increasingly prevalent in marine near-shore environments so has concern for potential environmental damage. Numerous studies have demonstrated alterations of the benthos beneath and proximal to net-pens (Table 1). Effects are generally restricted to within $30 \mathrm{~m}$ of the pens and the magnitude of the effects has been categorized from 'no gross impact' (e.g. Frid \& Mercer 1989) to 'highly eutrophicated' (e g. Hall et al. 1990). Although effects have been documented, interpretation has been on a site by site basis due, in part, to the failure of linear models to relate benthic loading to benthic impacts, as well as the assumption that a single benthic assimilative capacity is applicable to all sea bottoms (e.g. Silvert 1992). It is clear that the first 7 effects documented in Table 1 are either direct or in-

\footnotetext{
-Present address: Department of Microbiology, Miami University, Oxford, Ohio 45056, USA.

E-mail: rfindlay@miavx1.muohio.edu
}

direct consequences of increased benthic metabolism. Recent developments in our understanding of benthicpelagic coupling suggest these responses can be directly linked to increases in carbon flux to the benthos (Nixon 1981, Hargrave 1984, Sampou \& Oviatt 1991, Kemp \& Boynton 1992, Hatcher et al. 1994).

The 2 main processes associated with organic matter degradation in shallow-water marine systems are the delivery of particulate organic matter from the water column to the benthos, and benthic decomposition and resulting solute fluxes. Recent developments in sediment trap technologies have greatly improved our ability to measure benthic carbon flux. Cylindrical traps should have the appropriate diameter to match the flow characteristics of the environment and aspect ratios $>3.5$ to minimize trap sampling bias (Butman 1986, Butman et al. 1986, Baker et al. 1988). In shallowwater systems resuspension followed by settling can confound measurements of deposition, but a comparison of the organic and inorganic content of sediments can be used to correct for the effect of resuspension on deposition rates (Kemp \& Boynton 1992) 
Table 1 Effects of fish net-pen culture on benthos beneath and proximal to net-pens

\begin{tabular}{|c|c|}
\hline Effect & Citation \\
\hline $\begin{array}{l}\text { Increased sediment } \\
\text { carbon inventories }\end{array}$ & $\begin{array}{l}\text { Brown et al. (1987), Rosenthal et al. (1988) and citations within, Hall et al. (1990), } \\
\text { Weston (1990), Hansen et al. (1991), Ye et al. (1991), Hargrave et al. (1993) }\end{array}$ \\
\hline $\begin{array}{l}\text { Decreased sediment } \\
\text { redox potential }\end{array}$ & $\begin{array}{l}\text { Brown et al. (1987), Gowen \& Bradbury (1987), Rosenthal et al. (1988) and citations } \\
\text { within, Wildish et al. (1988), Lumb \& Fowler (1989), O'Connor et a1. (1989). Wilctish et al. (1990), } \\
\text { Hargrave et al. (1993) }\end{array}$ \\
\hline $\begin{array}{l}\text { Increased benthic } \\
\text { metabolism measured } \\
\text { as } \mathrm{O}_{2} \text { or } \mathrm{CO}_{2} \text { flux rates }\end{array}$ & $\begin{array}{l}\text { Gowen \& Bradbury (1987), Rosenthal et al. (1988) and citations within, } \\
\text { Hall et al. (1990), Hansen et al. (1991), Holmer \& Kristensen (1992), } \\
\text { Hargrave et al. (1993), Findlay et al. (1995) }\end{array}$ \\
\hline $\begin{array}{l}\text { Increased } \mathrm{H}_{2} \mathrm{~S} \text { and } \\
\text { methane flux from } \\
\text { the sediments }\end{array}$ & $\begin{array}{l}\text { Brown et al. (1987), Gowen \& Bradbury (1987), Rosenthal et al. (1988) and citations } \\
\text { with.n, Lumb \& Fowler (1989), Hall et al. (1990), Weston (1990). Hansen et al. (1991). } \\
\text { Holmer \& Kristensen (1992) }\end{array}$ \\
\hline $\begin{array}{l}\text { Increased nutrient } \\
\text { flux from sediment }\end{array}$ & $\begin{array}{l}\text { Gowen \& Bradbury (1987), Rosenthal et al. (1988) and citations within, Hansen et } \\
\text { al. (1991), Holby \& Hall (1991), Hargrave et al. (1993) }\end{array}$ \\
\hline $\begin{array}{l}\text { Altered microbial } \\
\text { community structure }\end{array}$ & $\begin{array}{l}\text { Brown et al. (1987). Gowen \& Bradbury (1987), Rosenthal et al. (1988) and citations } \\
\text { within, Lumb \& Fowler (1989), Findlay et al. (1995) }\end{array}$ \\
\hline $\begin{array}{l}\text { Altered macrofauna } \\
\text { abundance and } \\
\text { community structure }\end{array}$ & $\begin{array}{l}\text { Brown et al. (1987), Gowen \& Bradbury (1987), Rosenthal et al. (1988) and citations } \\
\text { within, O'Connor et al. (1989), Weston (1990), Lim (1991), Ye et al. (1991), } \\
\text { Findlay et al. (1995) }\end{array}$ \\
\hline $\begin{array}{l}\text { Increased carbon } \\
\text { flux to the benthos }\end{array}$ & Hall et al. (1990), Ye et al. (1991\}, Findlay et al. (1995), Tsutsumi (1995) \\
\hline
\end{tabular}

In several manipulative experiments, marine sediments enriched with organic matter showed increases in total benthic metabolism measured as $\mathrm{CO}_{2}$ flux from and $\mathrm{O}_{2}$ flux to the benthos (Anderson \& Hargrave 1984, Keplay \& Andersen 1985, Schwinghamer \& Keplay 1987. Sampou \& Oviatt 1991, Schwinghamer et al. 1991). In most of these experiments water movement was restricted and enrichment was sufficient to generate an oxygen demand greater than the supply deliverable by diffusion. Decomposition was mediated by anaerobic processes and virtually all oxygen consumption could be related to the reoxidation of reduced alternative electron acceptors. Under these conditions natural sediments will be devoid of macrofauna and sulfide-oxidizing bacteria will form mats at the watersediment interface.

We reasoned that if the ability of the benthos to oxidize organic matter aerobically could be determined and compared to the organic flux originating from the net-pens, a prediction of benthic impact would result As the State of Maine, USA (site of our study) has chosen the occurrence of azoic conditions or the development of Beggiatoa sp. mats as defining an unacceptable benthic impact (Sowles et al. 1994), we chose these criteria as the endpoints of our model and focused on the factors that control the balance between aerobic and anaerobic metabolism in marine sediments. We broke the problem of siting net-pens into 2 halves: (1) predicting the impact of a known benthic carbon flux and (2) predicting a priori the flux from a net-pen system. Both are very significant problems and we have chosen to deal. with the first in this manu- script. The purpose of this paper is to describe the theoretical basis of our model and the relationship between benthic organic matter loading and benthic metabolism as it relates to sediments proximal to several salmon net-pens in Maine coastal waters. We have developed our model of benthic impact associated with net-pen aquaculture using 2 parameters oxygen supply to the sediments and sediment oxygen demand. We assumed that benthic metabolism, and therefore maximum sediment oxygen demand, would be limited by the maximum rate of oxygen delivery to the sediments. We calculated oxygen supply by assuming delivery by Fickian diffusion, using 3 key environmental variables: (1) flow velocity, (2) temperature, and (3) oxygen concentration of the bottom water. Sediment oxygen demand was predicted from measured carbon sedimentation. rates as they related to benthic respiration. Our results, if coupled with a predicative model of carbon flux from a net-pen systems (for examples see Gowen \& Bradbury 1987, Silvert 1992), will yield a tool that can potentially minimize the environmental impacts of salmonid net-pen culture through regulation during the siting process.

\section{MATERIALS AND METHODS}

Study sites. We studied 3 salmon net-pen facilities within Maine coastal waters (Fig. 1). The sites were: (1) 2 individual net-pens located on a single lease site in Toothacher Cove, Swans Island, (2) an erosional site in Eastport and (3) a depositional site in Eastport 


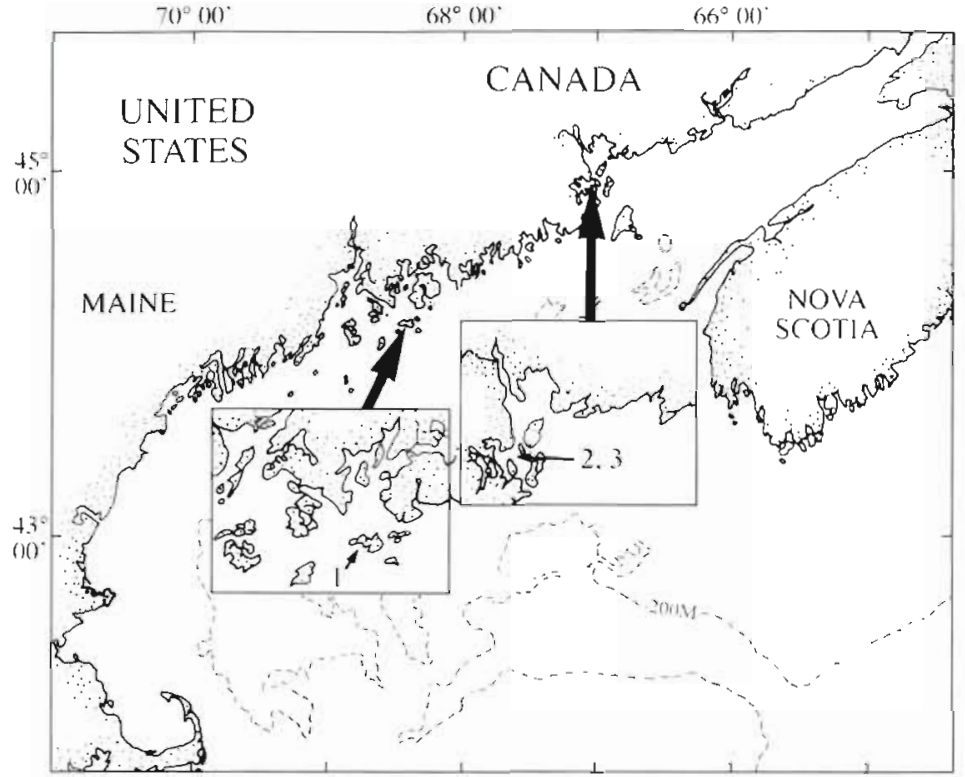

Fig. 1 Location of study sites

(Table 2). Exact biomass figures are not available, but we estimate that the Eastport depositional site contained approximately $250000 \mathrm{~kg}$ of fish biomass, the Eastport erosional site $41500 \mathrm{~kg}$ of fish biomass and the 2 net-pens at the Swans Island site 15000 and $7200 \mathrm{~kg}$ of fish, respectively. The Eastport sites were mature sites that had been in production for 7 to $10 \mathrm{yr}$ while the Swans Island sites had been in production for less than 3 yr. All sites were free of visible waste accumulation.

Experimental design. Permanent stations were developed at each study site. Concrete mooring blocks were positioned on the sea bottom directly below the edge of the net-pen being studied and a rope highway' constructed on the sea floor using braided nylon line that led to distal mooring blocks placed such that the ropes were parallel to the main current flows (currents at all sites were predominately bi-directional). Sampling stations were established at regular intervals along this transect. Sediment traps (2 each at the pen edges and at the ambient stations) were deployed at each sampling station and at the time of their recovery sediment cores for benthic metabolism ( 3 each) and microbial biomass (3 each) were taken. At selected intervals, cores for macrofaunal analysis were also taken. Samples reported in this study were taken directly beneath the down-current edge of a pen or pen complex (proximal sediments) and $100 \mathrm{~m}$ from the net-pen or pen complex (ambient or distal sediments). When possible, ambient stations were located perpendicular to the main current flow with respect to the net-pen or pen complex.

Sampling. We attempted to sample monthly throughout the year, but rarely were able to complete sampling during the winter months. All sediment traps and sediment cores were taken by SCUBA assisted divers. Cores used for benthic metabolism and microbial biomass were made from clear, $6.5 \mathrm{~cm}$ ID polycarbonate tubing Cores were carefully inserted into the sediments to a depth of approximately $10 \mathrm{~cm}$ and the top capped with a rubber stopper The diver then dug a small hole along the outside of the core and slipped a similar stopper under the core. The top stopper was loosened slightly (to allow pressure relief) and the bottom stopper firmly inserted into the core. The top stopper was then also firmly inserted. Cores were

Table 2. Summary of ambient physical and chemical characteristics of net-pen study site

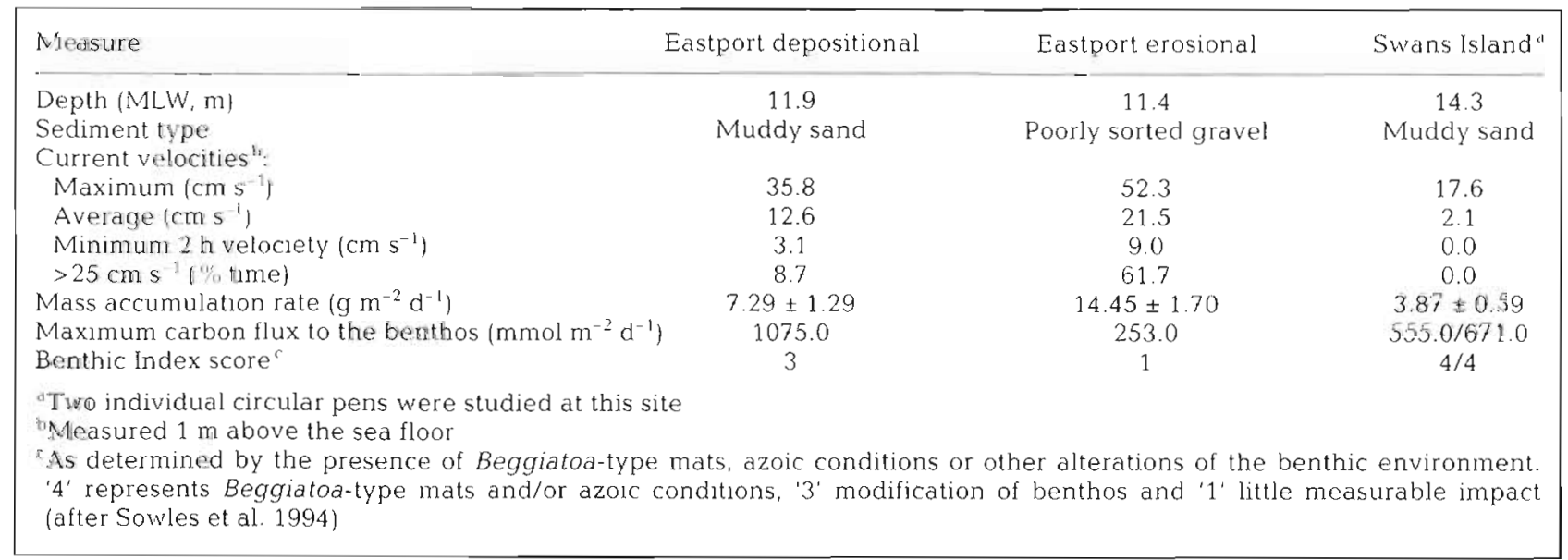


placed in a rack designed to maintain vertical orientation during recovery and were recovered by the dive tender by means of a marker buoy and recovery line. Only cores that showed no signs of sediment resuspension were accepted for analysis.

Physical and production data. Recording current meters (Endeco Model 105) were moored $1 \mathrm{~m}$ from the bottom at all sites and refreshed monthly. These meters provided an average current velocity and direction every $30 \mathrm{~min}$. The minimum current velocity detected by these meters was typically 0.15 to $0.30 \mathrm{~cm}$ $\mathrm{s}^{-1}$ Meters were calibrated before each use. Water depths, sediment granulometry, temperature data, the number and weight of fish per pen, the number, size, configuration and orientation of the pens in use, and the size and type of food being fed were (when possible) obtained from the firms involved and corroborated, when possible, by diver observations

Organic matter deposition. Carbon deposition was measured using sediment traps. Trap construction incorporated the latest technological suggestions (Butman 1986, Butman et al. 1986, Baker et al. 1988) and were designed to minimize sampling bias. Butman has clearly shown that the critical parameter is the relationship of trap diameter to current velocity. As such, we constructed traps from clear polycarbonate tubing, and matched trap diameter to the current velocity at each study site. Traps were either $37.5 \mathrm{~cm}$ in height and $10 \mathrm{~cm}$ in diameter (aspect ratio 3.75 ) and, at lowflow study sites, produced an appropriate Reynolds' number $\left(\mathrm{Rt}=1 \times 10^{4}\right)$ or were $37.5 \mathrm{~cm}$ in height and $6.5 \mathrm{~cm}$ in diameter (aspect ratio 5.77 ) and, at high-flow study sites, produced a similar Reynolds' number. Traps were placed in swivel-mounted holders with the trap mouth $1 \mathrm{~m}$ above the sediment-water interface. Due to the long trap deployment times ( $-30 \mathrm{~d})$, material collected in the traps was preserved with salt (TX-10, Akzo Salt, Inc.). The trapped material was sieved $(500 \mu \mathrm{m})$ to remove animals (e.g. copepods) that swam into the traps and were killed. Sieving also removed detritus $>500 \mu \mathrm{m}$. The removal of the $>500 \mu \mathrm{m}$ fraction decreased measured ambient and pen carbon flux rates by 10 to $100 \%$ fdepending on time of year), but the vast majority of this fraction was dead zooplankton. No significant differences in the carbon and nitrogen content of the $>500 \mu \mathrm{m}$ fraction from pen and ambient traps were detected. The amount of material collected in the traps was determined gravimetrically, corrected for any remaining salts, and total organic carbon and nitrogen content determined using a Carlo Erba elemental analyzer Sediment samples were first treated with fumes of hydrochloric acid to remove any inorganic carbon (usually present as calcium carbonate). Carbon deposition rates were corrected for sediment resuspension by assuming that all ash present within the trap originated from seabed sediment. The amount of carbon entering the trap due to resuspension of sediment was then estimated as: Carbon resuspension $=($ Trap ash content $\times$ Seabed sediment carbon content) $\times$ (Seabed sediment ash content) ${ }^{-1}$ The component of variation for duplicate traps was typically less than 10\%

Benthic metabolism. Benthic metabolism was measured as the rate of oxygen consumption and benthic $\sum \mathrm{CO}_{2}$ flux. The rate of oxygen consumption was estimated by measuring the loss of oxygen from the overlying water and benthic $\sum \mathrm{CO}_{2}$ flux was estimated by measuring accumulation of $\Sigma \mathrm{CO}_{2}$ in the overlying water over time. Undisturbed sediment cores were collected, immediately transported to shore-side facilities, the overlying water removed and replaced with ambient sea water and the cores sealed with a air-tight cap such that approximately $400 \mathrm{ml}$ of ambient sea water overlay the sediment. The underside of the sealing cap was fitted with a small, caged magnetic stir bar and the overlying water was stirred at approximately $5.0 \mathrm{~cm}$ $\mathrm{s}^{-1}$ Cores were incubated at ambient temperature for 1 to $4 \mathrm{~h}$ (depending on temperature) in the dark Oxygen concentrations declined 20 to $50 \%$ during the incubation period. At the end of the incubation period the cores were unsealed and samples removed for oxygen and $\Sigma \mathrm{CO}_{2}$ determinations and the volume of the remaining water measured. Oxygen concentration was determined by microWinkler titration performed on site and $\mathrm{SCO}_{2}$ concentration was determined using the potentiometric Gran titration and the method of Edmond (1970) as modified (where appropriate) by Bradshaw et al. (1981). Water samples used for $\sum \mathrm{CO}_{2}$ determinations were fixed with $\mathrm{HgCl}_{2}$ and titrations were performed in the laboratory within $2 \mathrm{wk}$ of collection. The component of variation for triplicate determinations of oxygen uptake rates was typically less than $20 \%$ and for triplicate $2 \mathrm{CO}_{2}$ determinations was typically less than $25 \%$

Data presentation and analysis. Oxygen uptake, $\Sigma \mathrm{CO}_{2}$ production and carbon deposition rates are reported in the literature using a variety of units. To facilitate comparison between the various rates we have reported all rate measurements in units of $\mathrm{mmol}$ $\mathrm{m}^{-2} \mathrm{~d}^{-1}$. The relationships between $\mathrm{O}_{2}$ uptake, $\Sigma \mathrm{CO}_{2}$ production and carbon deposition were determined by linear regression analysis. As $\mathrm{O}_{2}$ consumption and $\Sigma \mathrm{CO}_{2}$ production were both measured during the determination of benthic metabolism, data from individual cores were compared. The relationship between carbon flux to the sediments and benthic metabolism was also determined by linear regression, but using mean values. The carbon flux to the sediment was determined using sediment traps (mean of 2 traps) deployed for 10 to $30 \mathrm{~d}$ prior to the determination 
of benthic metabolism. This value was compared to the mean ( 3 replicate analyses) $\mathrm{O}_{2}$ consumption or $\sum \mathrm{CO}_{2}$ production rates for that station at the date of the recovery of the sediment traps. Only 6 data points out of a possible 11 ( 4 were lost and 1 excluded) were used for the comparison of carbon sedimentation rate to $\Sigma \mathrm{CO}_{2}$ production due to losses of $\Sigma \mathrm{CO}_{2}$ production samples and exclusion of stations when Beggiatoatype mats were present (chemosynthetic activity strongly skewed $\sum \mathrm{CO}_{2}$ fluxes).

Oxygen supply to the benthos. We predicted maximum rates of benthic oxygen supply using Fick's first law:

$$
J=D\left(C_{\infty}-C_{0}\right) / Z_{j}
$$

where $D$ is the molecular diffusion coefficient of the solute at the ambient temperature (in $\mathrm{m}^{2} \mathrm{~h}^{-1}$ ); $\mathrm{C}_{\mathrm{m}}$ and $C_{0}$ are the solute concentrations in the bulk water and at the interface, respectively (in $\mathrm{mmol} \mathrm{m}^{-3}$ ); and $Z_{\partial}$ is the thickness of the diffusion boundary layer (in $\mathrm{m}$ ). The average thickness of the diffusive boundary layer $\left(Z_{a}\right)$ for current velocities between 0.3 and $7 \mathrm{~cm} \mathrm{~s}^{-1}$ and the $\mathrm{O}_{2}$ molecular diffusion constant at $15^{\circ} \mathrm{C}(D)$ were obtained from the literature (Jørgensen 1989, Broecker \& Peng 1974, respectively). Oxygen concentrations at $15^{\circ} \mathrm{C}$ at saturation and zero were used for $C_{0}$ and $C_{0}$. respectively.

\section{RESULTS}

\section{Oxygen supply to the benthos}

Field measurements supported the assumption of $\mathrm{O}_{2}$ saturation for the bulk water. The relationship between flow velocity and the predicted maximum rates of benthic oxygen supply by molecular diffusion was non-linear with greatest increases in flux occurring at the lowest current velocities (Fig. 2). We consider this prediction accurate within a narrow range of key environmental parameters but an underestimation for most sediments. We consider it valuable because many sediments proximal to net-pens are constrained such that the prediction is accurate, at least during key periods of the tidal cycle.

\section{Benthic carbon deposition rates and benthic metabolism}

Carbon sedimentation rates at ambient sites ranged

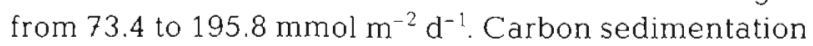
rates at sites proximal to net-pens ranged from 108.0 to $1075.0 \mathrm{mmol} \mathrm{m} \mathrm{m}^{-2} \mathrm{~d}^{-1}$. Losses during sampling and processing decreased the range of carbon sedimentation

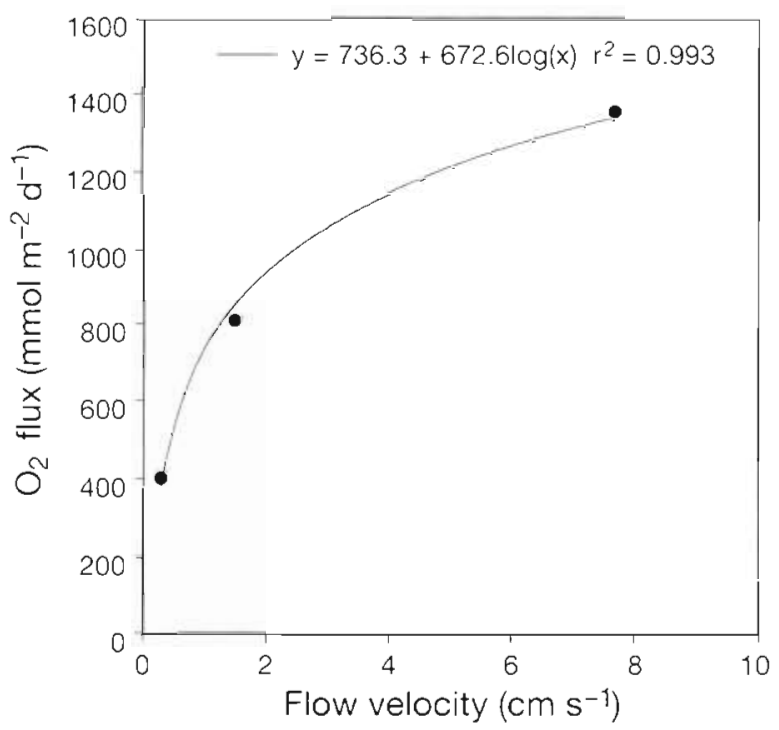

Fig. 2. Maximum Fickian diffusion of oxygen as a function of flow velocity, calculated using depths of diffusive boundary layer given in Jorgensen (1989) after Jorgensen \& Des Marais (1990). Rate was calculated for $15^{\circ} \mathrm{C}$ and the average $\mathrm{O}_{2}$ concentration at $15^{\circ} \mathrm{C}$ in the bottom water $\left(9.6 \mathrm{mg} \mathrm{l}^{-1}\right)$ during the 2 yr of the study

rates for which measurements of benthic metabolism were made to between 73.4 and $554.9 \mathrm{mmol} \mathrm{m}^{-2} \mathrm{~d}^{-1}$. Benthic metabolism was measured in 2 ways in this study; $\mathrm{O}_{2}$ flux rates and $\sum \mathrm{CO}_{2}$ production rates. Measured oxygen uptake rates ranged from 29.0 to $100.0 \mathrm{mmol} \mathrm{m} \mathrm{m}^{-2} \mathrm{~d}^{-1}$ in ambient sediments and 107.9 to $581.8 \mathrm{mmol} \mathrm{m}^{-2} \mathrm{~d}^{-1}$ in sediments proximal to net-pens. Carbon flux rates from sediments distal to the pens ranged from 42 to $167 \mathrm{mmol} \mathrm{C} \mathrm{m}^{-2} \mathrm{~d}^{-1}$ while flux rates from sediments proximal to salmon net-pens ranged from 152 to $384 \mathrm{mmol} \mathrm{C} \mathrm{m} \mathrm{d}^{-2} \mathrm{~d}^{-1}$ There was a strong linear relationship $\left(r^{2}=0.965\right)$ between organic carbon flux to sediment and benthic oxygen consumption (Fig. 3). The molar ratio of carbon flux to the benthos to $\mathrm{O}_{2}$ flux was near unity and this relationship was dominated by net-pen sediments. There was a strong 1:1 molar ratio (slope $=1.084, \mathrm{r}^{2}=0.936$ ) between the average daily carbon flux to the sediments and the benthic metabolism as estimated by $\Sigma \mathrm{CO}_{2}$ production if sediments covered with Beggiatod-type mats were not included in the analysis (Fig. 4).

Measurements of oxygen uptake and $\Sigma \mathrm{CO}_{2}$ production showed the most complex relationship. If sediments both proximal and distal to net-pens with $\mathrm{O}_{2}$ fluxes of $\leq 150 \mathrm{mmol} \mathrm{O}_{2} \mathrm{~m}^{-2} \mathrm{~d}^{-1}$ were considered, then a strong linear relationship $\left(r^{2}=0.697\right)$ between these 2 parameters was observed (Fig. 5a). The average respiratory quotient for these stations was 1.41. If all sediments proximal to the net-pens except those covered with Beggiatoa-type mats were included in 


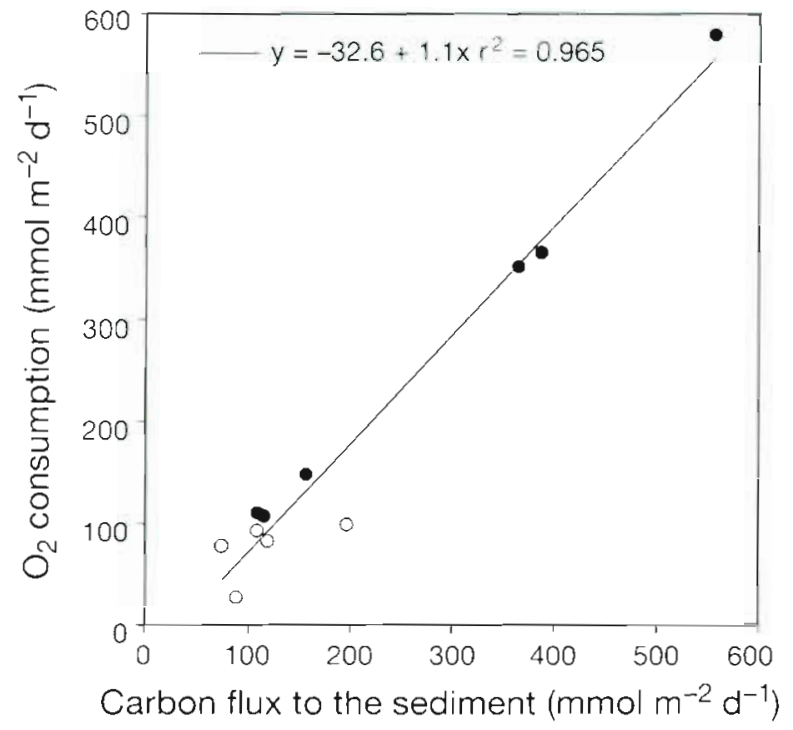

Fig. 3. Relationship between carbon flux to the sediment and benthic metabolism as measured by $\mathrm{O}_{2}$ consumption. (o) Sediments distal to salmon net-pens; $(\bullet)$ sedıments proximal to salmon net-pens

the analysis, a linear relationship was again observed $\left(\mathrm{r}^{2}=0.883\right)$ but the respiratory quotient dropped to 0.98 (Fig 5). Sediments covered with Beggiatoa-type mats showed respiratory quotients ranging from 0.12 to 0.38 and $\Sigma \mathrm{CO}_{2}$ flux from the sediments decreased with increasing $\mathrm{O}_{2}$ uptake rates.

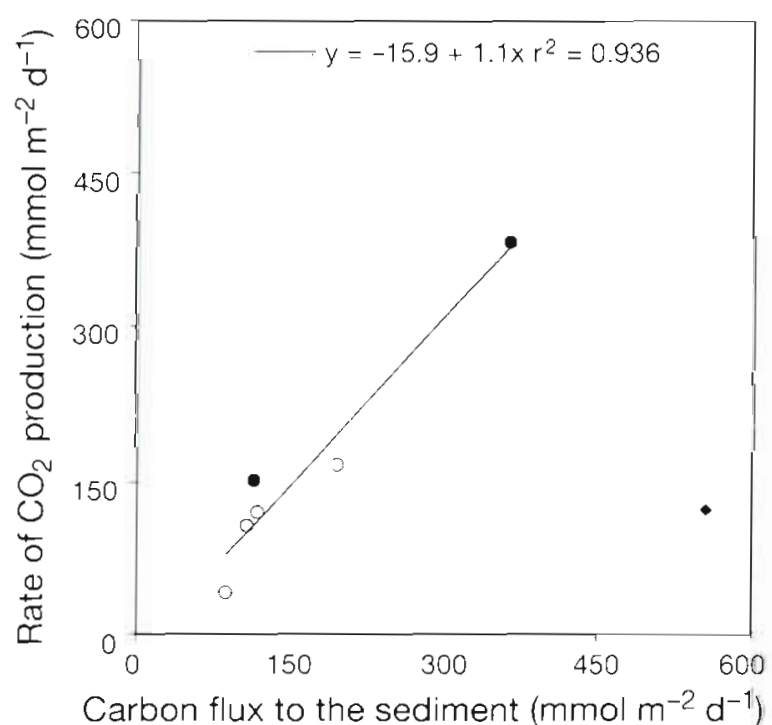

Fig. 4. Relationship between carbon flux to the sediment and benthic metabolism as measured by $\mathrm{CO}_{2}$ production. (0) Sediments distal to salmon net-pens, $\bullet$ sediments proximal to salmon net-pens. ( ) Sediments with visible Beggiatoa-type mats, not included in the regression analysis

\section{Benthic impact as a function of flow velocity and carbon flux to the benthos}

The 4 net-pen locations were compared on the basis of their maximum carbon sedimentation rates and minimum $2 \mathrm{~h}$ flow velocities (Fig 6). The 1:1 molar ratios between carbon deposition and $\mathrm{O}_{2}$ and $\mathrm{\Sigma CO}_{2}$ flux (Figs. $3 \& 4$ ) observed suggest that waste salmon food and feces are readily degradable and that sedimentation rates are a good predictor of the ultimate oxygen demand generated by the sediments. Minimum 2 h flow velocities were chosen as the key parameter to describe oxygen supply to the benthos because current velocities varied with tidal stage, and $2 \mathrm{~h}$ exposures to reduced oxygen and elevated hydrogen sulfide concentrations causes permanent damage to the gill tissues of sensitive infauna (Theede et al. 1969) The loss of macrofauna will shift apparent sediment oxygen diffusion coefficients toward the molecular coefficient - under these conditions Fickian diffusion constrains the maximal rate of oxygen delivery.

The circular net-pens located within Toothacher Cove had minimum $2 \mathrm{~h}$ flow velocities of $0.0 \mathrm{~cm} \mathrm{~s}^{-1}$ and moderate maximum carbon sedimentation rates. Their level of impact, however, was quite high with Beggiatoa-type mats forming beneath both pens (Findlay et al. 1995, authors' unpubl. obs.). In contrast, the Eastport depositional site had a much higher maximum carbon sedimentation rate; yet the benthos maintained

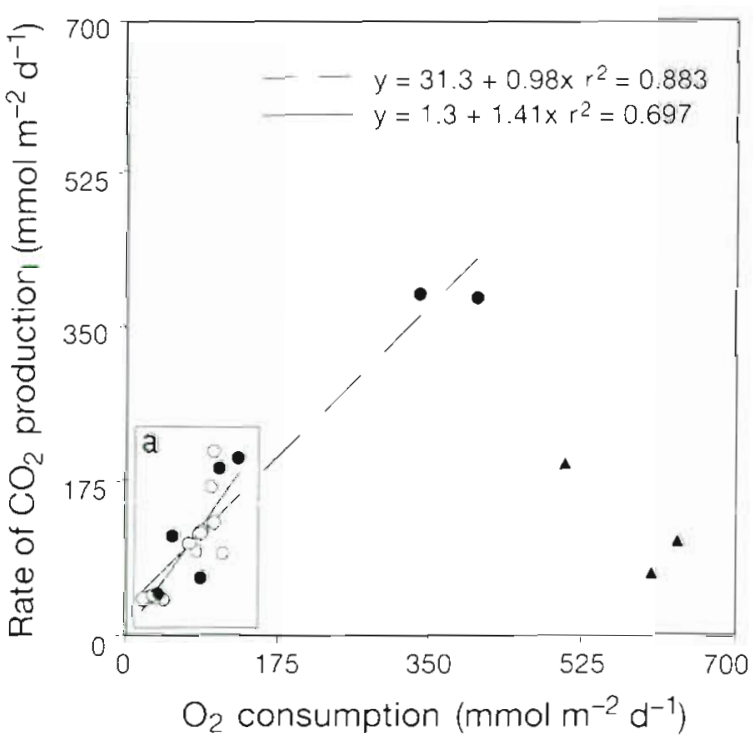

Fig. 5. Relationship between $\mathrm{O}_{2}$ consumption and $\mathrm{CO}_{2}$ production rates in sediments. Sediments with curbon sedimentation rates $\leq 150 \mathrm{mmol} \mathrm{m}^{-2} \mathrm{~d}^{-1}$ are detalled in the box (a) and are represented by the solud regression lıne. The relationship found for sediments proximal to salmon net-pens (excepting those with visible Beggiatoa-type mats) is given by the dashed regression line. Symbols as in Fig. 4 
Table 3. Comparison of carbon deposition and sedıment metabolic rates measured in this study to those reported for other salmond production sites. All values reported as mmol $m^{2} d^{1}$

\begin{tabular}{|c|c|c|c|}
\hline Parameter & This study & Literature range & Citations \\
\hline Carbon deposition & $108-1075$ & $106-6483$ & $\begin{array}{l}\text { Hall et al. (1990), Hansen et al. (1991) ', Ye et al. (1991), Hargrave } \\
\text { (1995), Tsutsum! (1995) }\end{array}$ \\
\hline Sediment $\mathrm{O}_{2}$ uptake & $108-582$ & $20-443$ & $\begin{array}{l}\text { Hall et al. (1990), Hansen et al. (1991), Hargrave ot al. (1993), } \\
\text { Wu et al. (1994) }\end{array}$ \\
\hline$\Sigma \mathrm{CO}_{2}$ production & $152-384$ & $32-619$ & Hall et al. (1990), Holmer \& Kristensen (1992) \\
\hline
\end{tabular}

a modified but aerobic community. Minimum 2 h flow velocities were $3.1 \mathrm{~cm} \mathrm{~s}^{-1}$. The benthic macrofaunal community beneath this pen system was abundant and diverse (Watling unpubl. data). The Eastport erosional site showed the highest flows (including minimum $2 \mathrm{~h}$ flow velocities) and the lowest carbon sedimentation rate. Using a suite of geochemical and biological indices, no benthic impact was detected at this pen system (authors' unpubl. data).

Two sites, Eastport depositional and Eastport erosional, showed carbon deposition rates (in mmol $\mathrm{m}^{-2}$ $\mathrm{d}^{-1}$ ) approximately equal to or less than the predicted oxygen supply rate (Fig. 6). These sites showed minimal impacts compared to other Maine sites (Table 2) and most sites from around the world (e.g Hall et al.

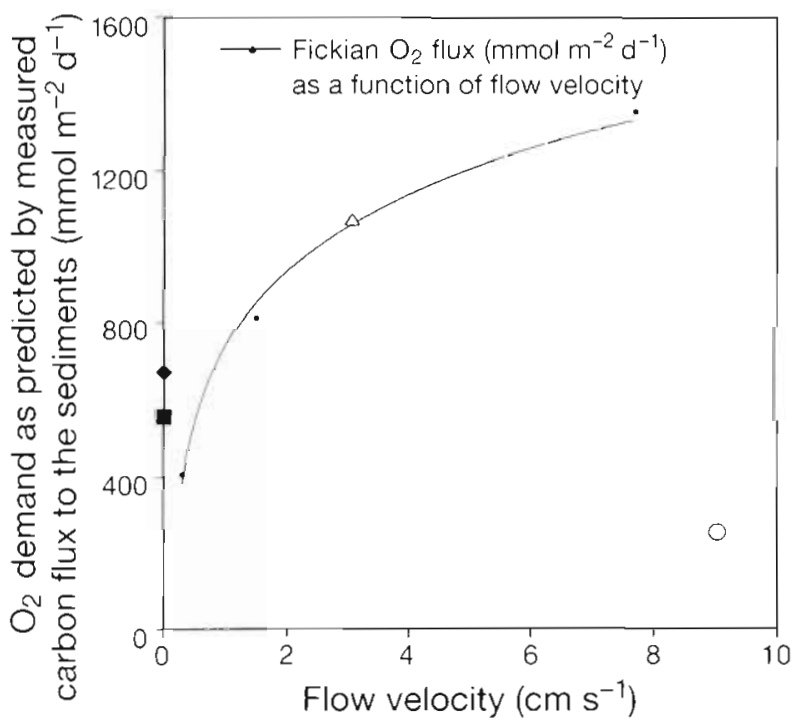

Fig. 6. Comparison of oxygen supply, as predicted from minimum flow velocity at each site and Fickian diffusion, to oxygen demand predicted from maximum carbon sedimentation rates. (-1) The 2 individual net-pens in Toothacher Cove (high benthic impact); ( $\Delta$ ) Eastport depositional site (moderate benthic impact); (o) Eastport erosional site (no detectable benthic impact). Physical and chemical characteristics of sites are given in Table 2
1990, Holmer \& Kristensen 1992, Hargrave et al. 1993). The 2 net-pens located in Toothacher Cove showed higher levels of impact than the Eastport sites even though their carbon deposition rates were approximately one-half to two-thirds the rate measured at the Eastport depositional site. We believe that the higher level of impact is due to the fact that oxygen demand exceeded supply. Oxygen supply at the Toothacher Cove locations was constrained by no-flow conditions not present at the Eastport sites.

\section{DISCUSSION}

Oxygen is delivered to sediments in shallow-water marine environments by a variety of mechanismsmolecular diffusion, bioturbation, and flow and wave advection. We have based our model on the delivery of oxygen by molecular, or Fickian, diffusion alone. We do so based upon the conditions encountered at many salmonid production sites that experience the azoic sediments/Beggiatoa-mat endpoint. Most, if not all, of the sites have minimum flow velocities of $<3.0 \mathrm{~cm} \mathrm{~s}^{-1}$ (for many minimum flow is $0.0 \mathrm{~cm} \mathrm{~s}^{-1}$ ). At these velocities pressure gradients are insufficient to generate advection (Huttel \& Gust 1992, Huttel et al. 1996). Wave advection, while possible in 10 to $15 \mathrm{~m}$ water depth, is a highly variable phenomenon in the sheltered coves and bays typical of net-pen aquaculture. Bioturbation will decrease in importance as the macrofaunal community experiences organic enrichment (moving from 'reference' through 'peak of opportunists' to 'azoic' sensu Pearson \& Rosenberg 1978), and, by definition, will not be a significant factor in azoic sediments. Bioroughness, a factor in both molecular diffusion and advection, will also be quite low at the azoic sediments/Beggiatoa-mat endpoint. Detailed drawings of Beggiatoa mats (Møller et al. 1985) indicate bioroughness on the order of $0.1 \mathrm{~mm}$. This is significantly less than the observed roughness of $\sim 3.0 \mathrm{~mm}$ for a photosynthetic microbial mat studied by Jorgensen \& Des Marais (1990) in which surface relief was found to 
increase diffusive flux by $49 \%$. Studies in shallow or intertidal sediments where apparent sediment diffusion coefficients for oxygen are compared to the molecular coefficients typically note apparent diffusion coefficients 2 to 3 times higher than the molecular coefficient (e.g. Andersen \& Helder 1987, Hofman et al. 1991). But these studies were also typically conducted using sediments with healthy macrofauna populations. Deep sea sediments are constrained in a fashion similar to salmonid production sites that experience the azoic sediment/Beggiatoa-mat endpoint (low to no flow, little bioturbation, low roughness); in these cases comparisons of apparent and molecular diffusion coefficients were in good agreement (Reimers et al. 1984, Reimers \& Smith 1986)

For our model to be applicable to salmonid production sites around the world, the rates measured in this study should be comparable to those at other sites or, if they are not, then critical biogeochemical processes should operate similarly over the range of rates reported for all sites. Carbon deposition rates measured in this study were within the range reported in the literature but maximum values were 6 -fold lower that the maximum value reported by Hall et al. (1990). In spite of this difference in benthic carbon flux, both sediment $\mathrm{O}_{2}$ uptake and $\sum \mathrm{CO}_{2}$ production rates measured in this study were comparable to those reported for other salmonid production sites (Table 3). As previously noted, none of the sites used in this study showed an accumulation of wastes beneath the net-pens, while this is commonly observed at sites with higher carbon flux rates (e.g. Hall et al. 1990, Hansen et al. 1991, Hargrave et al. 1993).

The observed correlation in the present study between $\mathrm{O}_{2}$ flux and sedimentation does not imply that aerobic decomposition is directly responsible for degradation of organic matter at these sites. Aerobic oxidation of organic carbon with a similar redox state as carbohydrate (e.g $\mathrm{CH}_{2} \mathrm{O}$ ) will produce 1 mole of $\mathrm{CO}_{2}$ for every mole of $\mathrm{O}_{2}$ consumed and a respiratory quotient (moles $\mathrm{CO}_{2}$ produced/ $\mathrm{O}_{2}$ consumed) of 1.0 . Respiratory quotients varied between sites and within sites depending on the rate of carbon flux to the benthos. For sediments, both proximal and distal, receiving organic carbon fluxes of $\leq 150 \mathrm{mmol} \mathrm{m} \mathrm{m}^{-2} \mathrm{~d}^{-1}$, the respiratory quotient averaged 1.4 (Fig. 5a). These values are within the range of respiratory quotients reported for sediments with active benthic fauna from around the world (Hargrave \& Phillips 1981, Mackin \& Swider 1989, Kristensen et al. 1991, Boucher et al. 1994). In marine sediments, respiratory quotients $>1$ have been interpreted to indicate active sulfate reduction with reduced sulfur retained at depth within the sediments (as $\mathrm{S}^{0}$ or $\mathrm{FeS}_{2}$, often temporally, if considered on an annual basis). Under this interpretation aerobic respiration plays a direct role in decomposition of organic matter (Jorgensen 1977, Sorensen et al. 1979, Jørgensen \& Sørensen 1985). Recent work suggests that this may not be the case le.g. Mackin \& Swider 1989, Ditoro et al. 1990) and that chemical oxidation of reduced metabolic endproducts produced by anaerobic decomposition of organic matter (frequently referred to as chemical oxygen demand) may account for the majority $\left(>90 \%\right.$ ) of benthic $\mathrm{O}_{2}$ fluxes. Holmer \& Kristensen (1992) and Hargrave et al. (1993) reported conditions beneath net-pen facilities exhibiting the azoic sediments/Beggiatoa-mat endpoint where chemical oxygen demand was sufficient to account for benthic $\mathrm{O}_{2}$ flux rates. Oxidation of $\mathrm{H}_{2} \mathrm{~S}$, produced during the anaerobic decomposition of organic matter by sulfate-reducing bacteria, is thought to be the major source of the chemical oxygen demand in marine sediments

Regardless of the pathway of organic matter decomposition, if the supply of oxygen is sufficient then hydrogen sulfide will not accumulate within surface sediments. This lack of accumulation may be the key to maintaining an active macrofaunal community and ultimately maintaining the assimilative capacity of the benthos. Conversely, the azoic sediments/Beggiatoamat endpoint is an indication that $\mathrm{H}_{2} \mathrm{~S}$ is present at the sediment surface (Jørgensen \& Revsbech 1983). As sulfide accumulates, a variety of metabolic processes may become inhibited and carbon preservation within the sediments enhanced (Hargrave et al. 1993). Measurements of $\mathrm{CO}_{2}$ production suggest that sediment metabolism is constrained in sediment impacted by wastes from salmonid production facilities. Maximum rates reported were $387 \mathrm{mmol} \mathrm{m} \mathrm{m}^{-2} \mathrm{~d}^{-1}$ (this study), $619 \mathrm{mmol} \mathrm{m}^{-2} \mathrm{~d}^{-1}$ (Holmer \& Kristensen 1992) and $553 \mathrm{mmol} \mathrm{m}^{-2} \mathrm{~d}^{-1}$ (Hall et al. 1990). These rates were all measured in sediments from environments with periods of zero flow but which differed by an order of magnitude in their rates of carbon sedimentation. If sulfate reduction rates are limited by the toxicity of $\mathrm{H}_{2} \mathrm{~S}$ to the anaerobic, fermentative bacteria that produce the substrates utilized by sulfate-reducing bacteria, then accumulation of organic matter under net-pen facilities would also be governed by oxygen supply and demand. Measurements of maximum $\mathrm{CO}_{2}$ production rates suggest that benthic accumulation of carbon would occur at sites with periods of no flow at benthic carbon flux rates of approximately $600 \mathrm{mmol} \mathrm{m}^{-2} \mathrm{~d}^{-1}$

Most salmonid aquaculture sites around the world report current ranges of 0 to $10 \mathrm{~cm} \mathrm{~s}^{-1}$ This suggests that these sites would experience significant periods of time with little or no flow and that they would be constrained by oxygen supply as were the Toothacher Cove sites. As such, a sedimentation rate in excess of

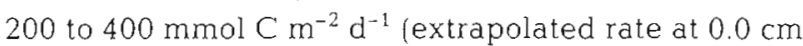


$\mathrm{s}^{-1}$ and the rate at $0.3 \mathrm{~cm} \mathrm{~s}^{-1}$ ) is predicted as the threshold value at which the azoic sediments/Beggiatoa-mat endpoint would be observed. In 2 cases where sedi-

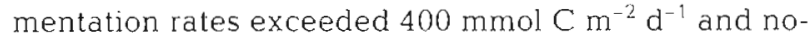
flow conditions were reported (Hall et al. 1990, Hansen et al. 1991), this endpoint was observed. Hargrave (1995) reported sedimentation rates of 100 to $117 \mathrm{mmol}$ $\mathrm{m}^{-2} \mathrm{~d}^{-1}$ at the pen edge and $650 \mathrm{mmol} \mathrm{m}^{-2} \mathrm{~d}^{-1}$ beneath the pens at the L'Etang Inlet site (New Brunswick, Canada). Impacts beneath the pens were consistent with the azoic sediments/Beggiatoa-mat endpoint but at the pen edge they were less severe (Hargrave et al. 1993). Ye et al. (1991) reported carbon sedimentation rates in excess of $400 \mathrm{mmol} \mathrm{m}^{-2} \mathrm{~d}^{-1}$ but only documented low to moderate benthic impacts at their site. No-flow conditions were not reported and average current velocities would have maintained oxygen supply in excess of oxygen demand as predicted from sedimentation rates.

\section{Model summary}

We have developed our model of benthic impact associated with net-pen aquaculture using 2 parameters: oxygen supply to the sediments and sediment

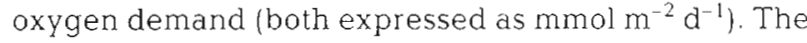
relationship between these 2 parameters can be examined in 2 ways, either graphically as in Fig 6 or by the calculation of an index of impact ( $I$ ) given as:

$$
I=\mathrm{O}_{2} \text { supply } / \mathrm{O}_{2} \text { demand }
$$

We calculate oxygen supply by assuming delivery by Fickian diffusion, using Eq. (1) and 3 key environmental variables: (1) flow velocity as the determinate of diffusive boundary layer thickness, (2) temperature, and (3) oxygen concentration of the bottom water. For $15^{\circ} \mathrm{C}$ and saturated bottom water we estimate:

$$
\mathrm{O}_{2} \text { supply }\left(\mathrm{mmol} \mathrm{m}{ }^{-2} \mathrm{~d}^{-1}\right)=736.3+672.5 \log (\mathrm{v})
$$

where $v$ is flow velocity in $\mathrm{cm} \mathrm{s}^{-1}$ (Fig 2)

Sediment oxygen demand is predicted from measured carbon sedimentation rates. Linear regression analysis of data from Maine production facilities yielded the equation used to convert carbon sedjmentation rates to sediment oxygen demand, that is:

$$
\mathrm{O}_{2} \text { demand }\left(\mathrm{mmol} \mathrm{m} \mathrm{m}^{-2} \mathrm{~d}^{-1}\right)=1.07 \mathrm{x}-32.6
$$

where $x$ is carbon flux to the benthos in mmol m $\mathrm{m}^{-2} \mathrm{~d}^{-1}$ (Fig. 3)

It is this balance between supply and demand that produces the prediction of impact. If the supply of oxygen is in excess of demand, then $I>1.0$, and impacts are minimal. If supply and demand are near unity, then $I \approx 1.0$, and impacts are moderate. If de- mand is in excess of supply, then $I<1.0$, and the sediments exhibit the azoic sediment/Beggiatoa-mat endpoint. We suspect, but were unable to investigate since Maine does not have sites with accumulated organic matter, that $I$ will be much less than 1.0 at sites where wastes form distinct deposits beneath the pens.

\section{Conclusions}

Flow velocities have long been recognized as important in predicting benthic impact associated with netpen aquaculture, but only as a mechanism by which waste feed and feces are distributed within the environment. Our study clearly demonstrates the pivotal role of flow in reducing the benthic impact of net-pens. Increased flow velocity not only reduces carbon sedimentation rates, but also results in increased sediment oxygen delivery, in turn allowing greater benthic degradation of the waste stream. We hypothesize that the non-linear increase in oxygen delivery with increasing flow was the major cause of the inability to predict impacts across a variety of sites.

As $\mathrm{O}_{2}$ supply is derived from an assumption that impacted sediments are constrained to oxygen delivery by Fickian diffusion and that this rate is under the control of a few key environmental variables, it is likely that the calculation of $\mathrm{O}_{2}$ supply will be robust across a variety of geographical or hydrological regions. This may or may not be the case for $\mathrm{O}_{2}$ demand. The calculation of $\mathrm{O}_{2}$ demand is based on an empirical relationship developed for a series of sites from coastal Maine and none of the sites used showed significant accumulation of organic wastes beneath the pens. Data from Hansen et al. (1991) suggests that a different ( 0.5:1) molar oxygen demand may be needed for longestablished facilities with visible waste accumulation. Regardless, if an accurate a priori prediction of benthic carbon flux can be made for proposed net-pen sites, then this model will be a useful tool for predicting levels of benthic impact. Studies of $\mathrm{SCO}_{2}$ flux rates suggest that oxygen supply to the sediments and its role in regulating sediment sulfide concentrations might be useful in predicting carbon sedimentation rates at which accumulation of waste deposits would occur This model may have general applicability to other types of organic enrichment if correlative studies linking carbon sedimentation rates to benthic $\mathrm{O}_{2}$ flux rates can be performed (as was done in this study) or if organic matter decay rate constants are known or can be determined for the introduced organic material.

This model synthesizes the understanding that sediment oxygen delivery and sediment oxygen consumption both play a role in determining benthic commu- 
nity structure and, if these 2 parameters are measured and compared, then the level of impact can be predicted for net-pen aquaculture. Key parameters become benthic carbon flux and oxygen delivery rates; comparison of these rates reveal whether the available carbon will be consumed aerobically with minimal environmental impact or anaerobically inducing environmental impact

Acknowledgements. This research was supported in part by grants from EPA Office of Exploratory Research (Assistance ID number R-817196-01-0), EPA District 1 (Assistance ID number X001837-01-0), National Marine Fisheries Service (U.S. Department of Commerce, National Oceanic and Atmospheric Administration, award number NA16FL0067-01), the UM/UNH Sea Grant College Program. (U.S. Department of Commerce, National Oceanic and Atmospheric Administration, project numbers R/FMD-215 and R/FMD-223), the Maine Aquaculture Innovation Center (project numbers 90-6, 91-13 and 93-081 and the PADl Foundation. We gratefully acknowledge the assistance of a great number of people whose efforts helped bring this project to fruition. These include E. Harrison, R. Doering, T Sawyer, J B. Pelletier, L. Klippel, L. McCann, M. Tarrentino, W. Tripp, J. Anderson, J. Fay, D. Meisenheimer, and C. Heinıg and B. Tarbox of Intertide Corp. for assistance with diving and field operatıons. $M$. Tarrentino and J. B. Pelletier ably served as dive safety off1cers and $\mathrm{T}$ Sawyer directed field operations in the absence of R.H.F. R. Doening, K. Hardy and L. Schick performed the CHN analyses and K. Hardy, L. Klippel and J. B. Pelletier processed the sediment trap samples.

\section{LITERATURE CITED}

Anderson Fø. Hargrave BT (1984) Effects of Spartina detritus enrichment on aerobic/anaerobic benthic metabolism in an intertidal sediment. Mar Ecol Prog Ser 16:161-171

Andersen FO. Helder W (1987) Comparison of oxygen microgradients, oxygen flux rates and electron transport system activity in coastal marine sediments. Mar Ecol Prog Ser 37:259-226

Baker ET, Milburn. HB. Tennant D A (1988) Field assessment of sediment trap efficiency under varying flow conditions. J Mar Res 46:573-592

Boucher G, Clavier J, Garrique C (1994) Oxygen and carbon dioxide fluxes at the water-sediment interface of a tropical Iagoon. Mar Ecol Prog Ser 107:185-193

Bradshaw AL, Brewer PG. Shafer DK (1981) Measurements of total carbon dioxide and alkalınity by potentiometric titration in the GEOSECS program. Earth Planet Scl Lett 55 : $99-115$

Broecker WS, Peng TH (1974) Gas exchange rates between air and sea. Tellus 26:21-35

Brown JR, Gowen RJ, McLusky DS (1987) The effect of salmon farming on the benthos of a Scottish sea loch. J Exp Mar Biol Ecol 109:39-51

Butman CA (1986) Sediment trap biases in turbulent flows: results of a laboratory flume study. J Mar Res 44:645-693

Butman CA, Grant WD, Stolzenbach KD (1986) Predictions of sediment trap biases in turbulent flows: a theoretical analysis based on observations from the literature. J Mar Res 44:601-644

DiToro DM, Paquin PR, Subburamu K. Gruber DA (1990)
Sediment oxygen demand model: methane and ammonia oxidation. J Environ Eng (NY) 116:945-986

Edmond JM (1970) High precision determination of titration alkalinity and total carbon dioxide content of sea water by potentiometric titration. Deep Sea Res 17:737-750

Findlay RH, Watling L, Mayer LM (1995) Environmental impact of salmon net-pen culture on Maine marine benthic communities: a case study. Estuaries 18:145-179

Frid CLJ, Mercer TS (1989) Environmental monitoring of caged fish farming in macrotidal envıronments. Mar Pollut Bull 20.379-383

Gowen RJ, Bradbury NB (1987) The ecological impacts of salmonid farming in coastal waters: a review. Oceanogr Mar Biol Annu Rev 25:563-575

Hall POJ, Anderson LC, Holby O, Kollberg S, Samuelsson $M O(1990)$ Chemical fluxes and mass balances in a marine fish cage farm. 1. Carbon. Mar Ecol Prog Ser 61:61-73

Hansen PK, Pittman K, Ervik A (1991) Organic waster from marine fish farms-effects on the seabed. In: Mäkinen I (ed) Marine aquaculture and the environment. Valtion Painatuskeskus OY, Helsinki, p 105-120

Hargrave BT (1984) Sinking of particulate matter from the surface water of the ocean. In: Hobbie JE, Williams PJLeb (eds) Heterotrophic activity in the sea. Plenum Press, New York, p 155-178

Hargrave BT (1995) A benthic enrichment index. Can Tech Rep Fish Aquat Sci 1949

Hargrave BT, Duplisea DE, Pfeiffer E, Wildish DJ (1993) Seasonal changes in benthic fluxes of dissolved oxygen and ammonium associated with marine cultured Atlantıc salmon. Mar Ecol Prog Ser 96:249-257

Hargrave BT, Phillips GA (1981) Annual in situ carbon dioxide and oxygen flux across a subtidal marine sediment. Estuar Coast Shelf Sc1 12:725-737

Hatcher AJ, Grant J, Schofield B (1994) The effects of suspended mussel culture (Mytilus spp.) on sedimentation, benthic respiration, and sediment nutrient dynamics in a coastal bay. Mar Ecol Prog Ser 115:219-235

Hofman PAG, de Jong SA, Wagenvoort EJ, Sandee AJJ (1991) Apparent sediment diffusion coefficients for oxygen and oxygen consumption rates measured with microelectrodes and bell jars: applications to oxygen budgets in estuarine intertidal sediments (Oosterschelde, SW Netherlands). Mar Ecol Prog Ser 69:261-272

Holby O. Hall POJ (1991) Chemical fluxes and mass balances in a marine fish cage farm. II. Phosphorus. Mar Ecol Prog Ser 70:263--272

Holmer M, Kristensen E (1992) Impact of marine fish cage farming on metabolism and sulfate reduction of underlying sediments. Mar Ecol Prog Ser 80:191-201.

Huettel M. Gust G (1992) Impact of bioroughness on intertucial solute exchange in permeable sediments. Mar Ecol Prog Ser 84:253-267

Huettel $M$, Zlebis W, Foster S 11996) Flow induced uptake of particulate matter in purmeable sea beds. Limnol Oceanogr 41:309-322

Jorgensen BB (1977) The sulfur rycle of a coastal marine sediment (Limfjorden, Denmark). Limnol Oceanogr 223: $814-832$

Jørgensen BB (1989) Diffusion microgradients and microbial respiration in interface environments. In: Hattorl $T$, Ishida Y, Maruyama Y, Morita RY, Uchida A (eds) Recent advances in microbial ecology. Japan Scientific Societies Press, Tokyo, p 103-107

Jargensen BB, Des Marais DJ (1990) The diffusive boundary layer of sediments: oxygen microgradients over a microbial mat. Limnol Oceanugr 35:1343-13jj 
Jorgensen BB, Revsbech NP (1983) Colorless sulfur bacteria, Beggratoa spp. and Thovolum spp., in $\mathrm{O}_{2}$ and $\mathrm{H}_{2} \mathrm{~S}$ microgradients. Appl Environ Microbiol 45:1261-1270

Jorgensen $\mathrm{BB}$, Sorensen $\mathrm{J}$ (1985) Seasonal cycles of $\mathrm{O}_{2}, \mathrm{~N}($ ). and $\mathrm{SO}_{4}{ }^{2-}$ reduction in estuarine sediments: the signuf. cance of an $\mathrm{NO}_{3}$ reduction maximum in spring. Mar Ecol Prog Ser 24:65-74

Kemp WM, Boynton WR (1992) Benthic-pelagic interactions: nutrient and oxygen dynamics. In: Smith EE, Leffler $M$, Mackiernan B (eds) Oxygen dynamics in the Chesapeake Bay. Maryland Sea Grant, College Park, Maryland, p 149-221

Keplay PE, Andersen FO (1985) Aerobic and anaerobic metabolism of a sediment enriched with Spartina detritus. Mar Biol 21:153-161

Kristensen E, Holmer M, Bussarawit N (1991) Benthıc metabolism and sulfate reduction in a southeast Astan mangrove swamp. Mar Ecol Prog Ser 73:93-103

Lim S (1991) Environmental impact of salmon farming on the benthic community in the Bay of Fundy. Bull Aquacult Assoc Canada 91:102-104

Lumb CM, Fowler SL (1989) Assessing the benthic impact of fish farming. In: McManus J, Elliott M (eds) Developments in estuarine and coastal study techniques. Olsen \& Olsen, Fredensborg, p 75-78

Mackin JE, Swider KT (1989) Organic matter decompositıon pathways and oxygen consumption in coastal marine sediments. J Mar Res 47:681-716

Moller MM, Nielsen LP, Jorgensen BB (1985) Oxygen responses and mat formation by Beggiatoa spp. Appl Environ Microbiol 50:373-382

Nixon SW (1981) Remineralization and nutrient cycling in coastal marine ecosystems. ln: Nellson BJ, Cronin LE (eds) Nutrients and estuaries. Humana Press, New York, p $111-138$

O'Connor BDS, Costelloe J, Keegan BF, Rhoads DC (1989) The use of REMOTS technology in monitoring coastal enrichment resulting from mariculture. Mar Pollut Bull $20: 384-390$

Pearson TH, Rosenberg R (1978) Macrobenthic succession in relation to organic enrichment and pollution of the marine environment. Oceanogr Màr Bıl Annu Rev 16:229-311

Reimers CE, Kalhorn S, Emerson SR, Nealson KH (1984) Oxygen consumption rates in pelagic sediments from the Central Pacific: first estımates from microelectrode profiles. Geochim Cosmochim Acta 48:903-910

Reimers CE, Smith KL Jr (1986) Reconciling measured and predicted fluxes of oxygen across the deep sea sedimentwater interface. Limnol Oceanogr 31:305-318

This article was submitted to the editor
Rosenthal H, Weston D. Gowen R, Black E (1988) Environmental impact of mariculture. Cooperative Research Report No. 154, International Council for the Exploration of the Sea, Copenhagen

Sampou P, Oviatt CA (1991) A carbon budget for a eutrophic marine ecosystem and the role of sulfur metabolism in sedimentary carbon, oxygen and energy dynamics. J Mar Res 49:825-844

Schwinghamer P, Keplay PE (1987) Effects of experimental enrichment with Spartina detritus on sediment community biomass and metabolism. Biol Oceanogr 4:289-322

Schwinghamer P, Keplay PE, Fodd A (1991) Oxygen flux and communıty biomass structure associated with benthic photosynthesis and detritus decomposition. J Exp Mar Bıol Ecol 147:9-35

Silvert W (1992) Assessing environmental impacts of finfish aquaculture in marine waters. Aquaculture 107:67-79

Sørensen J, Jørgensen BB, Revsbech NP (1979) A comparison of oxygen, nitrate, and sulfate respiration in coastal marine sediments. Microb Ecol 5:105-115

Sowles JW, Churchill L, Silvert W (1994) The effect of benthic carbon loading on the degradation of bottom conditions under farm sites. Can Tech Rep Fish Aquat Scı 1949

Theede H, Ponat A, Hiroki K, Schlieper C (1969) Studies on the resistance of marine bottom invertebrates to oxygen-deficiency and hydrogen sulphide. Mar Biol 2: $325-377$

Tsutsumı H (1995) Impact of fish net-pen culture on the benthic environment of a cove in South Japan. Estuaries 18 $108-115$

Weston DP (1990) Quantitative examination of macrobenthic community changes along an organic enrichment gradient. Mar Ecol Prog Ser 61:233-244

Wildısh DJ, Martin JL, Wilson AJ, DeCoste AM (1988) Environmental monitoring of the Bay of Fundy salmonid mariculture industry during 1986 and 1987. Can Tech Rep Fish Aquat Sci 1648

Wildish DJ, Martin JL, Wilson AJ, Ringuette M (1990) Environmental monitoring of the Bay of Fundy salmonid mariculture industry during 1988-89. Can Tech Rep Fish Aquat Sci 1760

Wu RSS, Lam KS, Mackay SW, Lau TC, Yam V (1994) Impact of marine fish farming on water quality and bottom sediment: a case study in the sub-tropical environment. Mar Environ Res 38:115-145

Ye LX, Ritz DA, Fenton GE, Lewis ME (1991) Tracıng the influence on sediments of organic waste from a salmonid farm using stable isotope analysis. J Exp Mar Biol Ecol $145: 161-174$

Manuscript received: September 10, 1996 Revised version accepted: June 5, 1997 